\title{
湿田農村環境における日本脳炎，蜔虫および ツビニ鈎虫の家族集積性について
}

西田重 衛*

緒言

著者は，富山県の湿田農村作道地域において， 日本脳炎, 蜔虫およびッビ二鈎虫を対象とした不 顕性感染の検查成績を資料として，それぞれの家 族集積性を統計学的に検討し，その伝播様式を明 らかにした。

\section{家族集栍性の検定方法}

（1）先ず，同一家族内陽性者（感染者）数別の 站分布を，家族人員別に作成する。

（2）次に, 全体の平均陽性（感染）率 $\mathrm{p}$ を計算 する。

（3）その $p$ を用いて，二項分布から偶然事象と
しての期待值を計算する。例えば，家族人員 2 人 の場合, 2 人とも㓌性の確率は $\mathrm{q}^{2}(\mathrm{q}=1-p)$, 片 方のみ陽性の確率は $2 \mathrm{pq}, 2$ 人とも陽性の確率は p $\mathrm{p}^{2}$ であのので，それぞれの破率市 2 人家族の総世 帯数に乗じて, 期待值を得る。

（4）実際值と,期待值との差罣の有意性を $x^{2}$-検 定を用いて検澍する。

\section{成 績}

（1）蜎性日本脳炎の終滺した昭和 26 年 11 月 より 29 年 2 月にわたる間， 167 世帶 860 名の血 清について, 日本脳炎補体絬合反応を $3 \sim 5$ ケ月 間隔で，計 8 回継紿検查した成結定資料とした。 本病の最近の感染を知るためには，向清の補体結

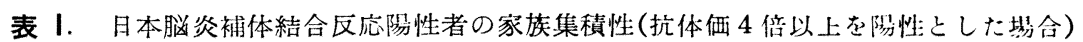

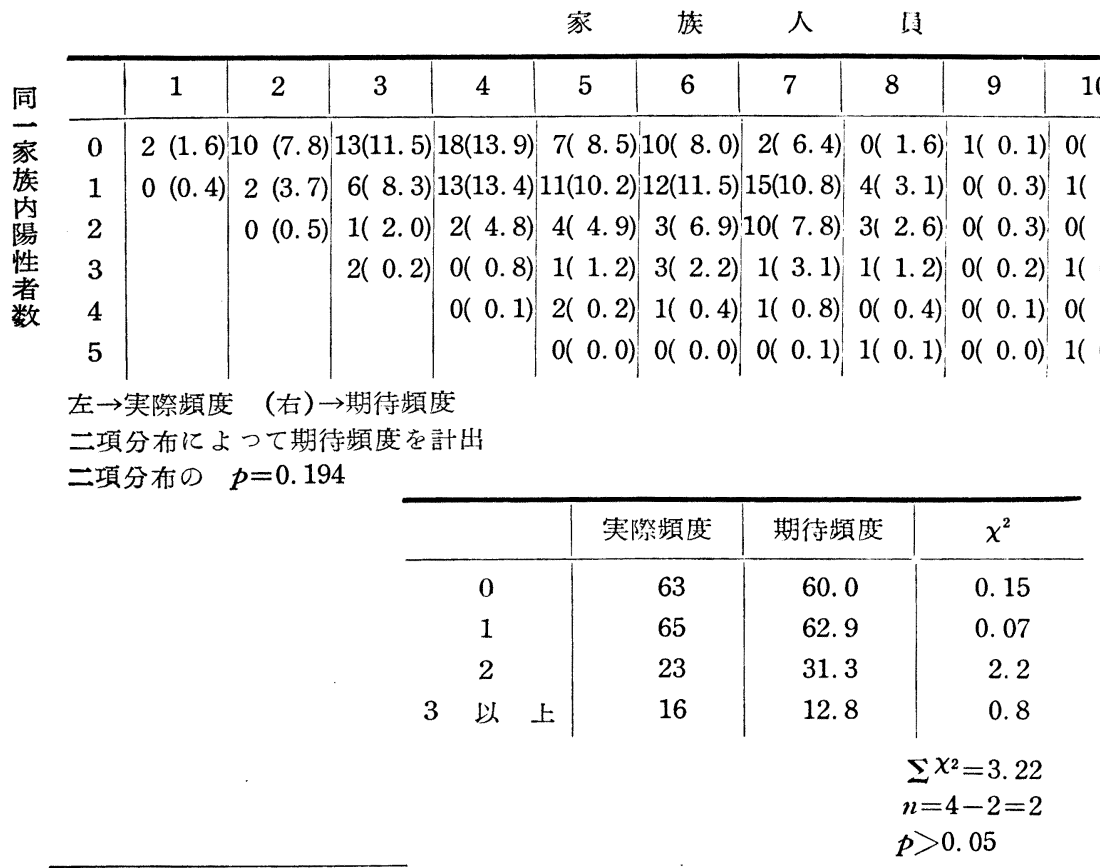

* 富山県 市立新潜病院作道分院 S. Nishida：The Familial Aggregation in Infection of Japanese B-Encephalitis Roundworm and Hookworm Helminthiasis in the Damp Rice Field Area. 
合反応検査を行うのが現今もっともよい方法であ って，一見健康なものに本反応が陽性に出るの は, 最近の不顕性感染によるものである（北岡(1) 徳田 $\left.{ }^{(2)}\right)$ 。陽性の確実を期するために, 抗体価 4 倍以上を陽性として，検査期間中における陽性者 の家族内集積を家族人員別にみると，表 1 のごと くである。ての度数分布に, 偶然事象としての理 論分布として，二項分布をあてはめてみると， (全体の平均陽性率を $p$ として計算), 実際值と期 待值との間に有意の差異がみとめられない。

換言すれば，陽性者の家族内集積は，偶然事象 としての二項分布に合致し，家族集皘性は証明さ
れない。ここには，検查期間中の全体の陽性者に ついての成績を示したが，さらに家族人数別（家 族人数別陽性率を $p$ として計算)，部落別，年令 階層別，検査時期別，次いで各期陽転者について も検討したが，いずれの場合も集積性は全く証明 されなかった（西田 $\left.{ }^{(3)}\right)$ 。

(2) 蜔 虫

昭和 26 年 8 月より 27 年 5 月までの間, 8 月, 12 月， 1 月および 5 月の 4 回にわたり，403 世帯 1908名について検便した成績を資料とした。ての 期間中における蜔虫卵保有者の家族内集積を家族 人員別にみると，表 2 のでとくである。乙の実際

表 2. 回虫卵㩐性者の家族集積性

家族人員

\begin{tabular}{|c|c|c|c|c|c|c|c|c|c|c|c|c|c|}
\hline & 1 & 2 & 3 & 4 & 5 & 6 & 7 & 8 & 9 & 10 & 11 & 12 & 計 \\
\hline 0 & $12(8$. & 5) $13(10$ & 1) $11(10$ & $\mid 11(6.1)$ & $4(3.0)$ & $8(13.3)$ & $6(0.6)$ & $0(0.1)$ & $0(0.0)$ & $0(0.0)$ & $0(0.0)$ & $0(0.0)$ & 65(39 \\
\hline 1 & $4(7$. & $14(17$. & $20(26$ & $17(21.8)$ & $17(13.3)$ & $9(6.8)$ & $6(3.5)$ & $2(0.5)$ & $2(0.3)$ & $1(0.0)$ & $0(0.0)$ & $0(0.0)$ & $92 / 98$ \\
\hline 2 & & 9) 8. & $24(23$. & $21(29.1)$ & $16(23.6)$ & $8(15.1)$ & $9(9.3)$ & $0(1.6)$ & $1(0.9)$ & $0(0.1)$ & $1(0.1)$ & $0(0.0)$ & $89(111$ \\
\hline 3 & & & $13(7$ & $20(17.2)$ & $19(21.0)$ & $12(17.9)$ & $4(13.7)$ & $3(2.9)$ & $2(1.9)$ & $0(0.3)$ & $0(0.2)$ & $0(0.1)$ & $73(82$ \\
\hline 4 & & & & $9(3.8)$ & $9(9.3)$ & 12(11.9) & $6(12.2)$ & $2(3.2)$ & $1(2.6)$ & $0(0.5)$ & $0(0.4)$ & $0(0.2)$ & $40(44$ \\
\hline 5 & & & & & $7(1.7)$ & $6(4.2)$ & $8(6.5)$ & $4(2.3)$ & $0(2.3)$ & $1(0.5)$ & $0(0.5)$ & $0(0.2)$ & $26(18$ \\
\hline 6 & & & & & & $3(0.6)$ & $7(1.9)$ & $0(1.0)$ & $0(1.4)$ & $0(0.4)$ & $0(0.4)$ & $O(0.2)$ & $10(5$ \\
\hline 7 & & & & & & & $2(0.2)$ & $0(0.3)$ & $1(0.5)$ & $0(0.2)$ & $0(0.3)$ & $0(0.2)$ & $\begin{array}{ll}) & 3(1 .\end{array}$ \\
\hline 8 & & & & & & & & $1(0.0)$ & $3(0.1)$ & $0(0.0)$ & $1(0.1)$ & $0(0.1)$ & $5(0$. \\
\hline
\end{tabular}

左 $\rightarrow$ 実際頻度，（右） $\rightarrow$ 期待頻度

二項分布によって期待頻度を計出

二項分布の $p=0.472$

\begin{tabular}{|c|c|c|c|c|}
\hline & & 実際頻度 & 期待頻度 & $\chi^{2}$ \\
\hline & 0 & 65 & 39.8 & 15.95 \\
\hline & 1 & 92 & 98.5 & 0.428 \\
\hline & 2 & 89 & 111.7 & 4.61 \\
\hline & 3 & 73 & 82.3 & 1.05 \\
\hline & 4 & 40 & 44.1 & 0.38 \\
\hline & 5 & 26 & 18. 2 & 3.34 \\
\hline 6 & 以上 & 18 & 7.9 & 12.91 \\
\hline & & & \multirow{2}{*}{\multicolumn{2}{|c|}{$\begin{array}{l}\sum \chi^{2}=38,668 \\
n=7-2=5\end{array}$}} \\
\hline & & & & \\
\hline & & & \multicolumn{2}{|c|}{$p<0.01$} \\
\hline
\end{tabular}

值は二項分布から計算した期待値との間に有意の 差異がみとめられる。換言すれば，陽性者の家族 内集積は，偶然事象としての二項分布とかけはな れており，明嘹な家族集積性が証明される。
（3）鈎 虫

昭和 26 年 8 月より 27 年 5 月までの間， 8 月， 12月，1月および 5 月の 4 回にわたり，405 世帯 1903名について検便した成績を資料としだ。この 
表 3. 銁 虫卵陽性者の家族集積性

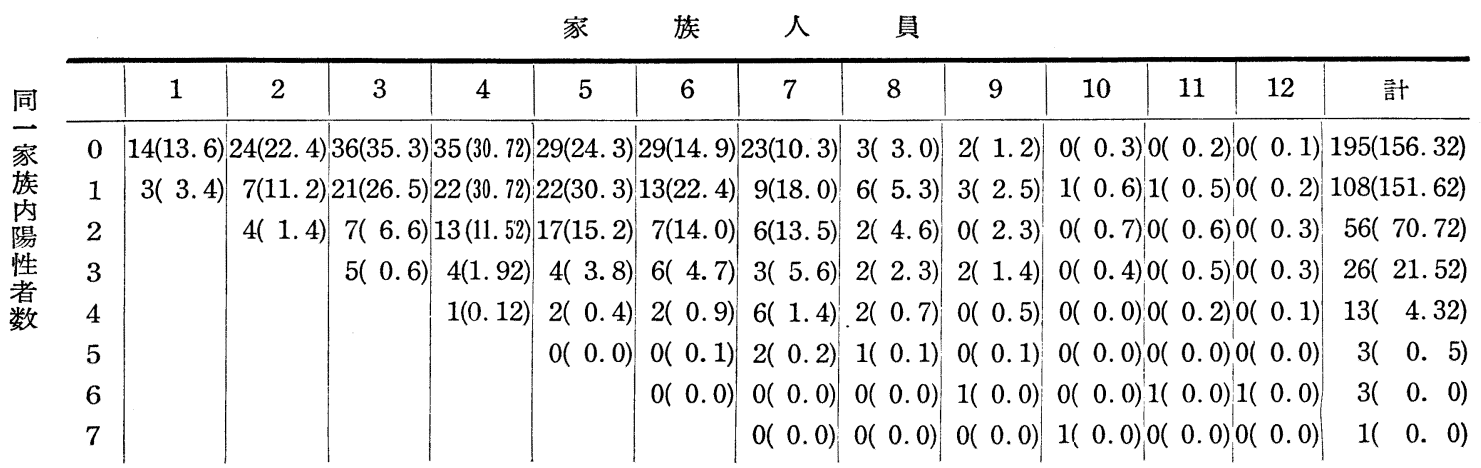

左 $\rightarrow$ 実際頻度 (右) $\rightarrow$ 期待頻度

二項分布によって期待頻度を計出

二項分布の $p=0.199$

\begin{tabular}{|c|c|c|c|c|}
\hline & & 実際頻度 & 期待頻度 & $\chi^{2}$ \\
\hline & 0 & 195 & 156.32 & 9.57 \\
\hline & 1 & 108 & 151.62 & 12.5 \\
\hline & 2 & 56 & 70.72 & 3.06 \\
\hline 3 & 以上 & 46 & 26.34 & 14.67 \\
\hline & & & \multirow{2}{*}{\multicolumn{2}{|c|}{$\begin{array}{c}\sum \chi^{2}=39.8 \\
n=4-2=2\end{array}$}} \\
\hline & & & & \\
\hline & & & \multicolumn{2}{|c|}{$p<0.01$} \\
\hline
\end{tabular}

期間中における鈎虫卵保有者の家族内集積を家族 人員別にみると表 3 のでとく，二項分布から計算 した期待值との間に有意の差異がみとめられ, 蜔 虫と同様に明瞭な家族集積性が証明される。富山 県における鈎虫は，東側地帯でツビ二鈎虫 $90 \%$, アメリカ鈎虫 $10 \%$ という報告があるが，当地域 ' (西側地帯) に扔ける著者の虫体検査では，360雙 すてべがツビニ鈎虫であった。

\section{考察}

家族集積性の検討, その有無の統計学的検定は, 伝染性疾患の伝播様式推定に欠くべからざる意義 をもっている。すなわち，人から人への逐次（連 鎖）伝播型であれば，(例，麻疹，百日咳）1軒 に 1 人感染者が出ると, 次々に感染者がその家族 内に続発するため, 明瞭な家族集積性が証明され る。一方共通経路型であれば（例，赤㾥や腸チフ スの水道流行)，全員が均等な感染機会をもつた め，通常家族 集積性は証明されない。したがっ て，家族集積性の有無を統計学的に検討するとと
によって，当該伝染性疾思が，逐次（連鎖）伝播 型か，共通経路型かを判別できるととになる（平 山(4) $^{(4)}$ 。

（1）従来日本脳炎の流行形式は，顕性思者によ って観察されて来た。しかし頙性思者となって現 われるのは山脈の高峰をみるようなもので，その 下には数十，数百倍の不顕性感染がかくれてい る。したがって日本脳炎の伝播様式は，不顕性感 染でみなければ本当のところはわからない。との 場合補体結合反応陽性者は, 本病の最近の感染を 示すものであるから，家族集積性の証明されなか ったてとより，本病は，人から人へと逐次伝播す るものでなく，何らかの共通経路によって伝播す るものであることが，不䫟性感染の立場から明確 になったわけである。

（2）蜔虫の場合は前記日本脳炎と異って，明瞭 な家族集積性が証明され，人から人へと逐次伝播 するものであることが確められた。

近時本病の風䈍感染が強調されているが，もし 本病の瞢延に風砧感染が主役を演じているとする 
ならば，感染源は家庭の内外にわたって共通経路 感染となるから，家族集積性は証明されないはず である。したがって, 当地域における本病の主た る感染経路は, 風䬺感染ではなく, 粪便経口感染 であると考えられる。

（3）ツビ二鈎虫の場合も，蛔虫と同様明瞭な家 族集積性が証明され，逐次(連鎖)伝播型をとって いる。鈎虫の感染経路には経皮, 経口の 2 つがあ るが，実際に意義の多いのは前者であると考光る 人が多い。ツビ二鈎虫はアメリカ鈎虫と異って, 肺を通ることを要せずして経口感染が可能である という実験的証明もあるが(横川, 蒲池 $\left.{ }^{(5)}\right)$, 本病 の主要感染経路がもし経口感染であれば, 蜔虫と 同様当然家族集積性が証明される。また経皮感染 であっても，自家人肥を施用する家族には，感染 源が家庭外の田畑にあっても, 他の家族員は耕作 にはとんど立入らないので，同じく家族集積性が 証明されるであろう。しかしながら，同じ資料で 観察した次の成繢より，当地域におけるッビ二鈎 虫の主要感染経路は, 経口感染であると考えられ る。

（イ）農家，非農家別に鈎虫简生率をみると表 4 のごとく，両群の間に有意の差異をみとめな い。

表 4. 宸家, 非農家别鈎虫等生率

\begin{tabular}{|c|c|c|c|c|}
\hline & & 検査人員 & 鈎虫卵 $(+)$ & \\
\hline 農 & 家 & 2137 & $396(18.4 \%)$ & $\chi^{2}=1.9$ \\
\hline 非 農 & 家 & 272 & $41(15.1 \%)$ & $p>0.05$ \\
\hline
\end{tabular}

（口）非農家で畑をもたないものの寄生率は表 5 のごとく，14.4\% で，乙れは地域の平均寄生 率 $18.1 \%$ に近く, 有畑の寄生率 $16.2 \%$ と大差を みとめない。

表 5. 非農家有畑, 無畑別鈎虫寄生率

\begin{tabular}{ll|r|r|l}
\hline & 検查人員 & 鈎虫卵 $(+)$ & \\
\hline 有 & 畑 & 99 & $16(16.2 \%)$ & $\chi^{2}=1.1$ \\
無 & 畑 & 173 & $25(14.4 \%)$ & $\begin{array}{l}n=1 \\
p>0.05\end{array}$
\end{tabular}

（八）濃厚污染部落の有卵者を, 蜄耕従事者と 非従事者とに分けてみると, 前者は91名中 49 名, 後者は 42 名で, 両者の間に大差をみとめない。 当地域では, 多くの農家は田畑ともに人肥を施
用し, とくに烟地には新鮮自家人肥を追肥してい る。人肥施用別に寄生率をみると, 新鮮人肥施用 度の高い部落程寄生率が高かった $\left(\right.$ 西田 $\left.{ }^{(6)}\right)$ 。もし 経皮感染が主であるならば，人䣏と接触の多い農 家, とくに農耕従事者に寄生率が高く, 無畑の非 農家はもっと低いはずである。

（二）湦厚感染家族例（表 6) では，幼少から 脳性小児麻痺で歩行の全くできない，10才の女児 にも鈎虫寄生がみとめられた。乙の女児の場合 は, その日常生活加ら経皮感染は考光られず, 明 らかに経口感染である。

表 6. 鈎虫濃厚感染家族例

\begin{tabular}{|c|c|c|c|c|c|c|c|c|}
\hline \multirow{2}{*}{ 氏名 } & \multirow{2}{*}{ 年令 } & \multirow{2}{*}{ 性別 } & \multicolumn{2}{|c|}{ 便虫卵 } & \multirow{2}{*}{ 既 往 症 } & \multirow{2}{*}{ 職 } & \multirow{2}{*}{ 業 } & \multirow{2}{*}{$\begin{array}{l}\text { 家 庭 } \\
\text { 環 境 }\end{array}$} \\
\hline & & & 蛔虫 & 鈎虫 & & & & \\
\hline 1 & 44 & $\delta$ & $(-)$ & $(+)$ & 脚気, 肺炎 & 僵 & 侶 & 寺 院 \\
\hline 2 & 70 & 우 & $(+)$ & $(+)$ & 石 & & & 田なし \\
\hline 3 & 45 & 우 & $(+)$ & $(-)$ & 肺 & 教 & 師 & 畑20路 \\
\hline 4 & 14 & $\delta$ & $(+)$ & $(+)$ & & 学 & 生 & 畑は人 \\
\hline 5 & 11 & $\uparrow$ & $(+)$ & $(-)$ & & 学 & 生 & 肥使用 \\
\hline 6 & 8 & 우 & $(-)$ & $(+)$ & 脳性小紧麻瘏 & & & \\
\hline 7 & 4 & $\delta$ & $(-)$ & $(-)$ & 大腸 炎 & & & \\
\hline
\end{tabular}

\section{結論}

富山県の一湿田農村における日本脳炎, 蜔虫お よびッビ二鈎虫の感染者について，それぞれの家 族集積性を統計学的に検討した。

日本脳炎では家族集積性が証明されず，その伝 播様式は共通経路型と考えられた。蜔虫および・. ビ二鈎虫では，いずれも明瞭な集積性が証明 れ，伝播様式は逐次（連鎖）伝播型であるとと 確められた。当地域における鈎虫疫学調查成績 綜合すると, ツビ二鈎虫の主要感染経路は, 従” よくいわれている経皮感染というよりも，むし乡 経口感染であると考えられた。

\section{参 考 交 献}

（1）北岡正見, 大久保薰, 馬場貞義：日本脳炎におけ る補体結合区忘, 特に燮断的価值, 日本脳炎調查研 究協議会編，日本脳炎，1948～49年，103～118

（2）徳田正夫：日本脳炎 B型，特にその補体結合反応 について 大阪医科大学雑誌, 12巻, 1 号, 1951

（3）西田重衛：日本脳炎感染の家族集積性に関する血 
清没学的研究, 日本伝染病学会誌, 31巻 3 号, 1957

(4) 平山 雄: 伝染病の家族集積性と, それに影㗽を 及ほす諸因子 衛生統計, 3 巻, 2 号, 1950

（5）横川定，蒲池勇三：鈎虫類の感染経路に関する実
的研究, 日本寄生虫学会記事, 第14年, 昭和17年

（6）西田重衛：富山県作道村にわける鈎虫寄生の度学 的考察，日本宸村医学会雑誌，1 巻，2〜3号, 1953

\title{
THE FAMILIAL AGGREGATION IN INFECTION OF JAPANESE B-ENCEPHALITIS, ROUNDWORM AND HOOKWORM HELMINTHIASIS IN THE DAMP RICE FIELD AREA. (SUMMARY)
}

\author{
Shigee Nishida \\ Shinminato Municipal Hospital
}

The statistical observation on the familial aggregation in infection of Japanese B-Encephaphalitis, Roundworm and Hookworm Helminthiasis was conducted on the result of complement fixation test of Japanese B-Encephalitis and examination of faeces for the inhabitants in damp rice field area in Toyama Prefecture.

It revealed the follow!ng facts :

1) In the case of Japanese B-Encephalitis, no significant difference could be found between the actual familial aggregation and that of theoretical solution computed by binominal distribution. It proves that there is no familial aggregation in infection of this disease.

From this result, It is considered that the infection of this disease spreads through some common vechicle.

2) But in cases of infection in Roundworm and Hookworm Helminthiasis, significant difference could be found between the actual familial aggregation and the theoretical solution computed by binominal distribution.

It proves that there is obviously a familial aggregation in infection of this disease.

From this result, it was confirmed that the propagation of this disease is made one by one and from month to month. In the case of Dubini Hookworm Helminthiasis, from the result of epidemjological observation of Hookworm Helminthiasis in this area, it was also confirmed that the important part of the propagation (infection) is made through month despite the previous theory that the major part of the propagation is made through skin. 